\title{
Dietary soybean meal on growth and intestinal morphology of South American catfish, Rhamdia quelen, larvae
}

\author{
Farelo de soja em dietas para larvas de jundiá (Rhamdia quelen) sobre o crescimento e morfologia \\ intestinal
}

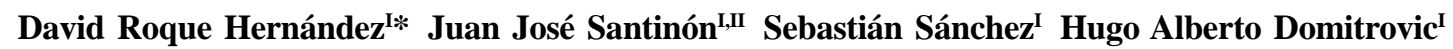

\begin{abstract}
The effects of the replacement of bread yeast by soybean meal in diets for Rhamdia quelen larvae on growth, survival, and intestinal morphology were analysed. Larvae were fed for 20 days with five diets: a control diet formulated with $57 \%$ of bread yeast, and other four diets in which soybean meal at concentrations of 14.25, 28.5, 42.75 and 57\% was added to obtain 25, 50, 75 and $100 \%$ of bread yeast replacement. Growth and survival parameters were negatively affected by dietary soybean meal inclusion. Larvae fed control diet showed significantly higher mean weight, specific growth rate, final biomass, and survival rate than larvae from other treatments. Enterocyte height and fold width of the posterior intestine showed highest values in the control group, and an inverse linear relationship with the level of dietary soybean meal inclusion was observed, however, in the anterior intestine the morphology parameters were not affected by the diet. These results indicate that inclusion of soybean meal in diets for $\boldsymbol{R}$. quelen larvae negatively affects growth and survival, as well as the capacity for digestion and absorption of nutrients, mainly in the posterior intestine.
\end{abstract}

Key words: larviculture, experimental diet, intestine, morphology, South American catfish.

\section{RESUMO}

Neste estudo, foi analisado o efeito da substituição de levedura de pão por farelo de soja em dietas para larvas de Rhamdia quelen no crescimento, sobrevivência e morfologia intestinal. As larvas foram alimentadas durante 20 dias com cinco dietas experimentais: uma dieta controle formulada com $57 \%$ de levedura de pão e quatro dietas em que o farelo de soja foi adicionado em 14,25, 28,5, 42,75 e 57\% para obter 25, 50, 75 e 100\% de substituição de levedura de pão. As variáveis de crescimento e sobrevivência foram negativamente afetadas pela inclusão da soja na dieta. As larvas alimentadas com a dieta controle apresentaram maior peso médio, taxa de crescimento específico, biomassa final e sobrevivência, diferindo significativamente dos demais tratamentos. A altura dos enterócitos e a largura das pregas no intestino posterior apresentaram valores mais elevados no grupo controle, enquanto nos demais tratamentos mostraram uma relação linear inversa com o nível de inclusão de farelo de soja na dieta. No entanto, no intestino anterior, os parâmetros morfológicos não foram afetados pela dieta. Esses resultados indicam que a inclusão de farelo de soja em dietas para larvas de $\boldsymbol{R}$. quelen afeta negativamente o crescimento e sobrevivência, bem como a capacidade de digestão e absorção de nutrientes, principalmente no intestino posterior.

Palavras-chave: larvicultura, rações experimentais, intestino, histologia, jundiá.

\section{INTRODUCTION}

In general, larviculture of fish and crustaceans under laboratory controlled conditions is carried out using live planktonic food, such as microalgae, rotifers, and Artemia sp. This activity involves some difficulty, because live food usually shows variable nutritional quality and inconstant supply, thus being a scarce and costly component (CONCEIÇÃO et al., 2009). Therefore, one of the challenges currently faced by aquaculture is the possibility of partly or totally replacing live food by

Instituto de Ictiología del Nordeste, Facultad de Ciencias Veterinarias, Universidad Nacional del Nordeste, (UNNE), Sargento Cabral 2139, Corrientes, Argentina. E-mail: dhernandez@vet.unne.edu.ar. *Autor para correspondência.

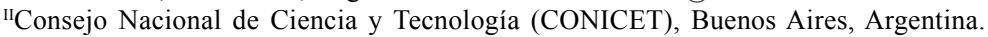


balanced diets at the first feeding stage (YÚFERA et al., 1999). Thus, the design and use of microdiets (MDs) for fish larvae is under full development as a factor of ecological sustainability and as technical-economical viability of the activity.

In order to fully or partially replace the use of fish meal in food production, due to its high cost and limited supply (HARDY, 2010), soybean meal appears as a suitable ingredient with several characteristics that make it favourable for its use in aquaculture (URÁN et al., 2008), such as its high protein level and good amino acid profile (BONALDO et al., 2006), and its secure supply (HARDY, 2010), being successfully used as food ingredient in some species (OLSEN et al., 2007). However, several studies have demonstrated that the use of soy products in fish diets can lead to an inflammatory state of the intestinal mucosa (OSTASZEWSKA et al. 2005; BONALDO et al. 2006; URÁN et al. 2008). Morphological changes depend on the tolerance of the species, the levels of inclusion of soy (ESCAFFRE et al. 2007), and different technological processes involved (REFSTIE et al. 2000).

In $\boldsymbol{R}$. quelen larvae, several MDs have been successfully tested, reaching higher values of weight gain and survival, being yeast (Saccharomyces cerevisiae) one of the most used ingredients (ULIANA et al., 2001; CARDOSO et al., 2004; HERNÁNDEZ et al., 2009). Considering that yeasts appear to be the most expensive ingredient in balanced diets production, in this study it is evaluated the effects of the replacement of bread yeast (BY) by soybean meal (SM) in increasing proportions in MDs for R. quelen larvae under controlled laboratory conditions, analysing growth and survival parameters, as well as it effect on intestinal morphology under light microscopy.

\section{MATERIALS AND METHODS}

The study was carried out at the experimental fish culture facilities of the Northeast Ichthyology Institute, School of Veterinary Sciences (Corrientes, Argentina), where 5MDs were evaluated in $\boldsymbol{R}$. quelen larvae. The experimental units were distributed according to a completely randomized design with 3 replicates $(n=15)$ for each feeding treatment.

\section{Experimental design and sampling}

After hatching, larvae were maintained in incubation chambers until almost complete absorption of the yolk sac and oral aperture (two days posthatching). At that moment, batches of 750 larvae (totalising 11,250 specimens) were placed in $1525-\mathrm{L}$ aquaria provided with supplementary aeration, used as experimental units ( 30 larvae $\left.\mathrm{L}^{-1}\right)$. Water replacement was carried out at a rate of $0.4 \mathrm{~L} \mathrm{~min}^{-1}$ during $12 \mathrm{~h} \mathrm{~d}^{-1}$ for waste elimination. The experiment lasted $21 \mathrm{~d}$, during which water temperature, conductivity $\left(\mu \mathrm{S} \mathrm{cm}^{-1}\right), \mathrm{pH}$ (HANNA ${ }^{\circledR}$ equipment), and dissolved oxygen ( $\mathrm{mg} \mathrm{L}^{-1}$, $\mathrm{YSI}^{\circledR}$ equipment) were recorded daily. MDs tested were the following: (Control) 57\% BY - 0\% SM, considered as control diet; (S1) $42.75 \% \mathrm{BY}-14.25 \% \mathrm{SM}$; (S2) 28.5\% BY - 28.5\% SM; (S3) 14.25\% BY - 42.75\% SM and (S4) $0 \%$ BY - 57\% SM. Each diet also contained fish egg $35 \%$, soy lecithin $2 \%$ and vitamin-mineral premix $6 \%$ (Table 1). To elaborate the balanced diets, the ingredients were mixed and sufficient water added $\left(400 \mathrm{~g} \mathrm{~kg}^{-1}\right)$ until form a soft dough. The resultant dough was passed through a mincer with $2 \mathrm{~mm}$ diameter mold and oven-dried $\left(38-40^{\circ} \mathrm{C}\right)$ for $48 \mathrm{~h}$ and stored at $-18 \mathrm{C}$ during the experiment. Each diet was ground and sieved according to the oral aperture of larvae with size particle of 100-200, 250-450 and 600-800 $\mu \mathrm{m}$, for the first, second, and third wk, respectively. All groups were daily fed ad libitum at $0800,1100,1400,1700$ and $2000 \mathrm{~h}$, throughout the experimental period.

Histological analysis

At the end of the experiment 30 larvae per treatment were collected and anaesthetized with tricaine methanesulphonate (MS222, 180 $\left.\mathrm{mg} \mathrm{L}^{-1}\right)$. The samples were formalin-fixed and routinely processed for histology by dehydration in graded ethanol, equilibration in xylene, and embedding in paraffin. Sections were cut about $3 \mu \mathrm{m}$ thick and stained with haematoxylin and eosin (HE). Mucins (carbohydrate compounds) were identified using histochemical methods. The sections were stained with periodic acidSchiff(PAS), then with alcian blue at $\mathrm{pH}$ 2.5-sialomucins (sialic acid) or sulfamucins (sulfate ester), fucsin aldehyde (sulfated glycoproteins), and a combination of these compounds. Histological analyses were carried out to evaluate the following morphological features of the anterior and posterior intestine: enterocyte height, intestinal mucosal folds (height and width), number of mucous cells and type of mucins (counted per 5 intestinal folds). Cell measurements were done using a Leica DM500 microscope and a Leica ICC50 digital camera. The values per treatment were taken with an image analysis system: Leica Application Suite 3.4.1.

\section{Data calculations and statistical analysis}

At the end of the experiment (21d), final mean weight (W) survival rates ( $\mathrm{S} \%$ ), and final biomass (FB) were estimated. Specific growth rate (HOPKINS, 1992) was calculated as $\mathrm{SGR}=100\left[\left(\ln W_{f}-\ln W_{i}\right)(\mathrm{T})^{-1}\right]$, were $\ln$ 
Table 1 - Ingredient composition of experimental diets used in first feeding of $\boldsymbol{R}$. quelen larvae $\left(\mathrm{g} \mathrm{kg}^{-1}\right)$ :

\begin{tabular}{|c|c|c|c|c|c|}
\hline \multirow{2}{*}{ Ingredient } & \multicolumn{5}{|c|}{ - } \\
\hline & Control & $\mathrm{S} 1$ & $\mathrm{~S} 2$ & S3 & $\mathrm{S} 4$ \\
\hline Bread yeast & 570 & 427.5 & 285 & 142.5 & -- \\
\hline Soybean meal & -- & 142.5 & 285 & 427.5 & 570 \\
\hline Fish egg & 350 & 350 & 350 & 350 & 350 \\
\hline Soy lecithin* & 20 & 20 & 20 & 20 & 20 \\
\hline Vitamin-mineral supplement $^{1}$ & 60 & 60 & 60 & 60 & 60 \\
\hline Crude protein & 444.5 & 434.4 & 423.8 & 410.4 & 397.0 \\
\hline
\end{tabular}

Control diet ( $0 \%$ soybean meal); S1, S2, S3, S4 (25, 50, 75 and $100 \%$ of bread yeast replacement, respectively).

1- Vitafac Super Acqua - Roche ${ }^{\circledR}$ (ingredient $\mathrm{kg}^{-1}$ of diet): vit. A: 144.000UI; vit. D3: 28.800UI; vit. E: 3.000mg; vit. K3: 96mg; vit. B1: 120mg; vit. B2: 240mg; vit. B6: 90mg; vit. B12: 0.36mg; vit. B8: 12mg; vit. B5: 480mg; Folic acid: 72mg; vit. B3: 1.800mg; vit. C: $1.800 \mathrm{mg}$; Se: 360mg; I: 20mg; Cu: 60mg; Zn: 840mg; Mn: 600mg; Fe: $1.200 \mathrm{mg}$; Co: 24mg.

* ULIANA et al. (2001).

is the natural logarithm of $W_{f}$ and $W_{i}$ expressed in mg of a determined period $(\mathrm{T})$.

The effects of the treatments on growth, survival, final biomass and histological parameters were evaluated using a one-way analysis of variance (ANOVA). Duncan test was used for a posteriori comparisons of means. Relationships between soybean meal inclusion level (SL: \%) and the other variables were examined using linear regression. Significance was accepted at $\mathrm{P}<0.05$. All statistical tests were carried out using the STATISTICA program for Windows, version 6.0.

\section{RESULTS AND DISCUSSION}

The growth parameters (W, SGR and FB), presented an inverse linear relationship with the percentage of addition of soybean meal $(\mathrm{P}<0.05)$ (Table 2 ). The highest $S \%$ were obtained in the control diet, showing significant differences with $\mathrm{S} 1, \mathrm{~S} 3$ and $\mathrm{S} 4$ diets $(\mathrm{P}<0.05)$, without presenting a significant linear relationship (Table 2).

On the other hand, no histopathological alterations were observed in the intestinal portions analysed. The enterocytes of the intestinal mucosa in $\boldsymbol{R}$. quelen larvae showed regular shape, containing clear cytoplasmatic vesicles in the anterior intestine and eosinophilic vesicles in the posterior intestine. However, morphological changes were observed in the posterior intestine in relation to the percentage of soybean meal added to the diet. Thus, differences were observed in enterocyte height and folds width, with the control diet corresponding to the highest values (27 and $24 \mu \mathrm{m}$, respectively) and an inverse linear relationship of these measurements with the level of soybean meal inclusion $(\mathrm{P}<0.05)$ (Table 2 and figure 1ac). It was also observed that the decrease in enterocyte size in the posterior intestine with increasing soybean meal incorporation was accompanied by lower amount of supranuclear eosinophilic vesicles (Figure 1d-f).

Fold height of both intestinal portions analysed did not show significant differences among the experimental groups $(\mathrm{P}>0.05)$ (Table 2$)$. The mucous cells, neutral and acid mucine producers, were observed throughout the intestine. The frequency in the anterior intestine portion increased from 1.9 cells per $100 \mu \mathrm{m}$ linear of mucosal folds to 3.3 in the posterior intestine portion, without differences among the experimental groups $(\mathrm{P}>0.05)$ (Table 2).

Studies about soybean meal inclusion in fish diets have shown a clear negative effect on growth and survival for most studied species, related to life stage, the level of inclusion, the degree of tolerance of the species and the industrialization process, among others (OSTASZEWSKA et al., 2005; BONALDO et al., 2006; REFSTIE et al., 2006; ESCAFFRE et al., 2007; URÁN et al. 2008). Also, in this study it was demonstrated that parameters of growth and survival in $\boldsymbol{R}$. quelen larvae presented a marked reduction with an increase of soybean meal in the MDs.

In agreement with the results obtained in the present study, the addition of soy produced a decrease of growth in Paralichthys olivaceus juveniles (DENG et al., 2006) and Leporinus obtusidens larvae (FILIPETTO et al., 2005). In contrast, ESCAFFRE et al. (1997) obtained better growths in Cyprinus carpio larvae using soy protein concentrate in diets. They observed that levels of 20 to $40 \%$ of soy inclusion did not affect development, although growth decreased with higher levels of soy inclusion. These authors considered that the absence of food in the digestive tract of larvae fed with diets with a high content of soy protein concentrate could be due to the decrease in palatability, 
Table 2 - Intestine morphometric parameters, survival, specific growth rate and weight of $\boldsymbol{R}$. quelen larvae fed with different soybean meal levels.

\begin{tabular}{|c|c|c|c|c|c|c|c|}
\hline \multirow{2}{*}{ Parameters } & \multicolumn{5}{|c|}{----------------------Experimental Diets---------------------- } & \multirow{2}{*}{ Linear Regression $^{1}$} & \multirow{2}{*}{$r^{2}$} \\
\hline & Control & $\mathrm{S} 1$ & $\mathrm{~S} 2$ & $\mathrm{~S} 3$ & S4 & & \\
\hline AI & 27.0 & 24.8 & 23.9 & 23.0 & 24.4 & $y=26.02-0.026 \mathrm{SL} \mathrm{ns}$ & 0.16 \\
\hline PI & $26.3^{\mathrm{a}}$ & $23.4^{\mathrm{ab}}$ & $21.4^{\mathrm{ab}}$ & $19.9^{\mathrm{ab}}$ & $17.9^{\mathrm{b}}$ & $y=25.79-0.074 \mathrm{SL} *$ & 0.42 \\
\hline \multicolumn{8}{|c|}{--Mucosa fold height---- } \\
\hline AI & 168.4 & 139.1 & 170.9 & 141.4 & 131.4 & $y=162.9-0.220 \mathrm{SL} \mathrm{ns}$ & 0.07 \\
\hline PI & 112.4 & 121.8 & 81.0 & 76.6 & 71.7 & $y=111.3-0.435 \mathrm{SL} \mathrm{ns}$ & 0.18 \\
\hline \multicolumn{8}{|c|}{--Mucosa fold width--- } \\
\hline AI & 23.7 & 21.8 & 20.7 & 21.1 & 19.1 & $y=23.40-0.033 \mathrm{SL}$ ns & 0.17 \\
\hline PI & $24.0^{\mathrm{a}}$ & $20.2^{\mathrm{ab}}$ & $17.9^{\mathrm{ab}}$ & $17.0^{\mathrm{ab}}$ & $14.0^{\mathrm{b}}$ & $y=23.20-0.082 \mathrm{SL} *$ & 0.47 \\
\hline $\mathrm{AI}$ & 2.1 & 2.5 & 2.0 & 1.8 & 1.8 & $y=2.225-0.004 \mathrm{SL} \mathrm{ns}$ & 0.25 \\
\hline PI & 3.5 & 4.1 & 2.7 & 3.7 & 3.2 & $y=3.460-0.002 \mathrm{SL} \mathrm{ns}$ & 0.02 \\
\hline--- & & -------- & et Cells & ber (BA & 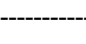 & & --- \\
\hline AI & 1.7 & 2.2 & 1.8 & 1.7 & 1.5 & $y=1.970-0.003 \mathrm{SL} \mathrm{ns}$ & 0.12 \\
\hline PI & 3.1 & 3.7 & 3.0 & 2.5 & 2.7 & $y=3.374-0.008 \mathrm{SL} \mathrm{ns}$ & 0.23 \\
\hline--- & & - n--- & let Cells & nber $(\mathrm{AI}$ & - & - & ---- \\
\hline AI & 1.8 & 1.9 & 1.8 & 1.8 & 1.4 & $y=1.882-0.003 \mathrm{SL} \mathrm{ns}$ & 0.17 \\
\hline PI & 3.6 & 4.0 & 3.0 & 3.8 & 2.7 & $y=3.771-0.007 \mathrm{SL} \mathrm{ns}$ & 0.15 \\
\hline AI & 1.9 & 2.2 & 1.9 & 1.8 & 1.5 & $y=2.079-0.004 \mathrm{SL} \mathrm{ns}$ & 0.26 \\
\hline PI & 3.4 & 3.9 & 2.9 & 3.3 & 2.9 & $y=3.610-0.006 \mathrm{SL} \mathrm{ns}$ & 0.16 \\
\hline $\mathrm{W}(\mathrm{mg})^{2}$ & $142.2^{\mathrm{a}}$ & $76.8^{\mathrm{ab}}$ & $56.6^{\mathrm{b}}$ & $39.5^{\mathrm{bc}}$ & $15.9^{\mathrm{c}}$ & $\operatorname{Ln} y=4.09-0.03 \mathrm{SL}^{*}$ & 0.73 \\
\hline SGR & $26.0^{\mathrm{a}}$ & $22.9^{\mathrm{ab}}$ & $20.9^{\mathrm{b}}$ & $19.2^{\mathrm{bc}}$ & $15.1^{\mathrm{c}}$ & $y=25.89-0.101 \mathrm{SL} *$ & 0.73 \\
\hline $\mathrm{S} \%$ & $72.4^{\mathrm{a}}$ & $53.0^{\mathrm{b}}$ & $59.6^{\mathrm{ab}}$ & $54.7^{\mathrm{b}}$ & $21.8^{\mathrm{c}}$ & $y=62.84-0.212 \mathrm{SL} \mathrm{ns}$ & 0.34 \\
\hline $\mathrm{FB}(\mathrm{g})^{2}$ & $35.3^{\mathrm{a}}$ & $21.8^{\mathrm{ab}}$ & $19.5^{\mathrm{ab}}$ & $12.2^{\mathrm{b}}$ & $0.98^{\mathrm{c}}$ & $\operatorname{Ln} y=11.28-0.78 \mathrm{SL}^{*}$ & 0.96 \\
\hline
\end{tabular}

${ }^{1}$ Linear regression: $y$ : expected values; SL: soybean meal replacement levels (\%); Asterisk $(*)$ : significant relationship $(\mathrm{P}<0.05)$; ns: no significant differences $(\mathrm{P}>0.05)$. $\mathrm{r}^{2}$ : determination coefficient.

${ }^{2}$ For the linear regression analysis, values of dependent variables were transformed to natural logarithms $(\mathrm{Ln})$.

AI: anterior intestine; PI: posterior intestine; PAS: periodic acid-Schiff; AB: alcian blue; FA: fucsin aldehyde; W: final weight; SGR: specific growth rate; S\%: survival; FB: final biomass. Different letters in the same line means statistical differences (Duncan test; $\mathrm{P}<0.05)$.

presence of antinutritional factors affecting trypsin activity, or insufficient input of essential amino acids.

Previous studies carried out in $\boldsymbol{R}$. quelen juveniles have demonstrated that it is possible to incorporate levels of up to $36 \%$ of soybean meal in combination with cane yeast at the same levels, providing good performances (COLDEBELLA \& RADÜNZ NETO, 2002). Such results contrast with the observations recorded in this study and those reported by PIAIA \& RADÜNZ NETO (1997) in R. quelen larvae fed with different protein sources. These authors observed that soy-based regimes were associated with low percentages of survival, independently of the remaining protein sources (vegetable or animal) used in their study. These results could indicate that the digestive system of $\boldsymbol{R}$. quelen larvae, immature at the beginning of the exogenous feeding and with alkaline digestion, would be inefficient to digest the soy components.

In this study, it is observed that the addition of soybean meal to the diets did not cause histopathological alterations in the gut of $\boldsymbol{R}$. quelen larvae. However, a decrease in morphological parameters in the posterior intestine was observed, related to an increase of soybean meal in the diet. Similarly, in Salmo salar (SISSENER et al., 2009) and in Sparus aurata (BONALDO et al., 2008), a negative effect associated to histological changes in the distal intestine was observed when soy was included in the diet.

In larvae, the posterior intestine plays a very important role in the processes of digestion and absorption of macronutrients. The capture of macromolecules by pynocitosis and their subsequent intracellular digestion in the posterior intestine has been 
proposed as the main mechanism for protein absorption during the absence of a functional stomach (GOVONI et al., 1986). In the present study, the absorption of proteins as supranuclear eosinophilic vesicles present into the enterocytes of the posterior intestine was observed in all treatments. However, the size of enterocytes showed a gradual decrease as soy content in the diets was increased, suggesting less macromolecules absorption by pynocitosis. Similar results were reported by BAEVERFJORD \& KROGDAHL (1996) in S. salar after six weeks of being fed with a diet containing $33 \%$ of soybean meal. In this context, young fish would be more sensitive to antinutritional factors present in soy (ESCAFFRE et al. 1997). In contrast, SANTIGOSA et al. (2010) showed that the addition of a purified trypsin inhibitor from soy to the feed of $\boldsymbol{S}$. aurata juveniles did not modify growth, proteolytic activity, or intestinal histological aspect when compared to fish fed a control diet. These authors suggested that intestinal alterations reported in other species could be the result of the incidence of other factors present in soy, such as lectins, alergenic proteins, or soluble alcohols. Diets for $\boldsymbol{S}$. salar juveniles that included soybean meal with reduced content of oligosaccharides and antinutritional factors produced similar results to those obtained with fish meal, while the inclusion of conventional soybean meal determined lower feeding conversion and lower growth, associated with low digestibility of soybean meal nutrients (REFSTIE et al., 1998).

In conclusion, this study shows that the use of soybean meal in diets for R. quelen larvae affects growth and survival, as well as their capacity of digestion and absorption of nutrients, mainly in the posterior intestine. It is recommend the use of soy components only for individuals in advanced stages of development.

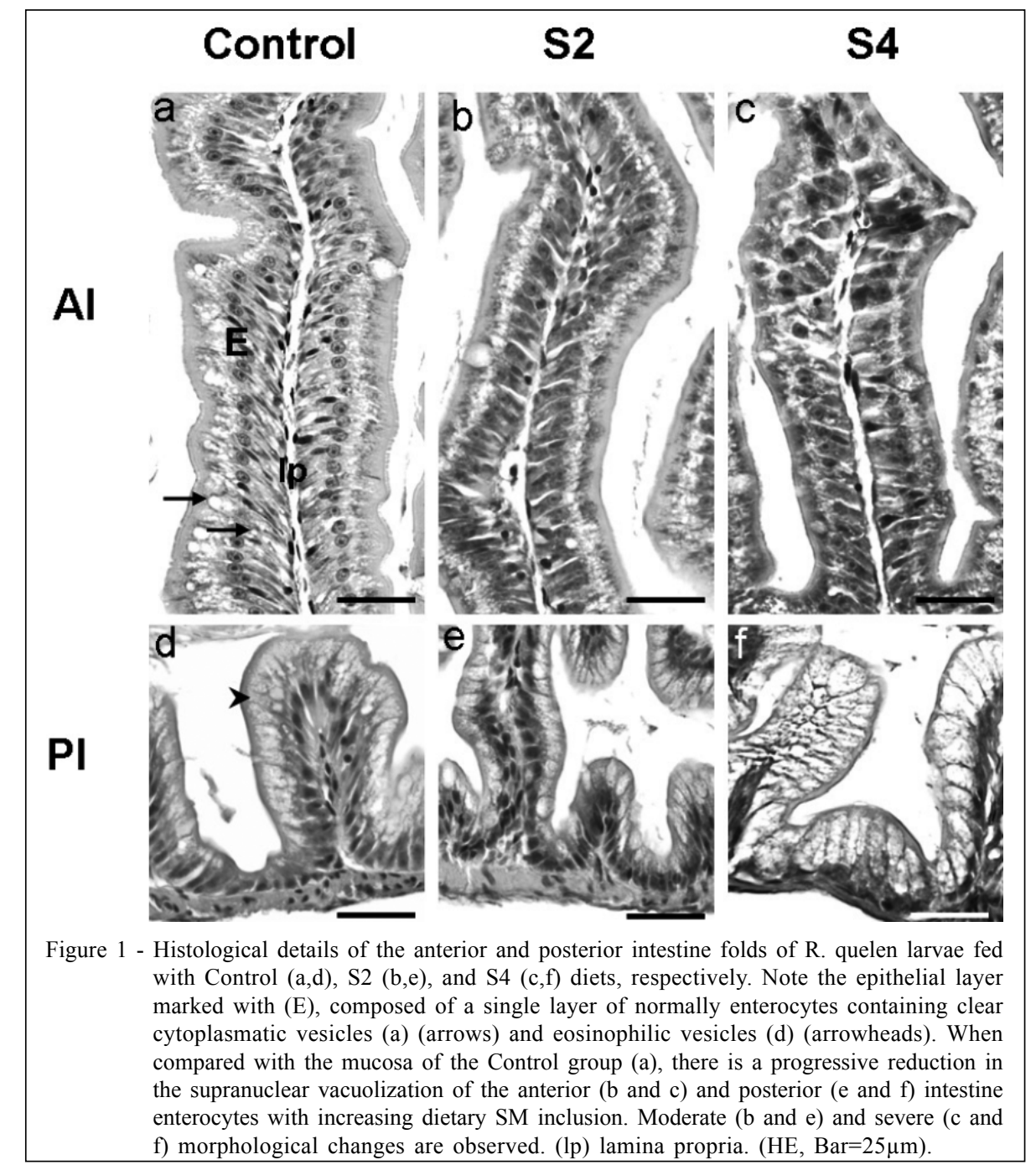

Ciência Rural, v.42, n.9, set, 2012. 


\section{ACKNOWLEDGEMENTS}

This research was supported by grants from the General Secretariat of Science and Technology of the Northeast National University, Argentine (project PI 001/2009) and the Argentinean National Agency for Scientific and Technological Promotion (project BID 1728/OC-AR PICTO-UNNE 161) given to DOMITROVIC, H.A. and SÁNCHEZ, S., respectively.

\section{ETHICS AND BIOSAFETY COMMITTEE}

The procedures adopted with the animals in this research were in accordance with the ethical principles of animal experimentation, and approved according to protocol n. 0001/ 14-2011-02827 by the Ethics and Biosafety Committee of School of Veterinary Sciences of the Northeast National University (UNNE) of Argentine.

\section{REFERENCES}

BAEVERFJORD, G.; KROGDAHL, A. Development and regression of soybean meal induced enteritis in Atlantic salmon, Salmo salar L., distal intestine: a comparison with the intestines of fasted fish. Journal of Fish Diseases, v.19, p.375-387, 1996. Available from: <http://onlinelibrary.wiley.com/doi/ 10.1046/j.1365-2761.1996.d01-92.x/pdf>. Accessed: dec. 20, 2010. doi: 10.1046/j.1365-2761.1996.d01-92.x.

BONALDO, A. et al. Influence of dietary levels of soybean meal on the performance and gut histology of gilthead sea bream (Sparus aurata L.) and European sea bass (Dicentrarchus Iabrax L.). Aquaculture Research, v.39, p.979-978, 2008 Available from: <http://onlinelibrary.wiley.com/doi/10.1111/ j.1365-2109.2008.01958.x/pdf >. Accessed: dec. 15, 2010. doi: $10.1111 /$ j.1365-2109.2008.01958.x.

BONALDO, A. et al. Influence of dietary soybean meal levels on growth, feed utilization and gut histology of Egyptian sole (Solea aegyptiaca) juveniles. Aquaculture, v.261, p.580586, 2006. Available from: <http://www.sciencedirect.com/ science/article/pii/S0044848606006399>. Accessed: dec. 20, 2010. doi: 10.1016/j.aquaculture.2006.08.013

CARDOSO, A.P. et al. Criação de larvas de jundiá (Rhamdia quelen) alimentadas com rações granuladas contendo fígados ou hidrolisados. Acta Scientiarum, v.26, p.457-462, 2004 Available from: <http://periodicos.uem.br/ojs/index.php/ ActaSciAnimSci/article/view/1718/1158>. Accessed: oct. 12, 2010. doi: 10.4025/actascianimsci.v26i4.1718.

COLDEBELLA, I.; RADÜNZ NETO, J. Farelo de soja na alimentação de alevinos de jundiá Rhamdia quelen. Ciência Rural, v.32, p.499-503, 2002. Available from: <http:// www.scielo.br/scielo.php?script $=$ sci_arttext\&pid $=\mathrm{S} 0103$ $84782002000300021 \& \operatorname{lng}=$ pt\&nrm $=$ iso $>$. Accessed: apr. 22, 2005. doi: http://dx.doi.org/10.1590/S0103-84782002000300021.

CONCEIÇÃO, L.E.C. et al. Live feeds for early stages of fish rearing. Aquaculture Research, v.41, p.613-640, 2009 Available from: <http://onlinelibrary.wiley.com/doi/10.1111/ j.1365-2109.2009.02242.x/pdf>. Accessed: oct. 30, 2011. doi 10.1111/j.1365-2109.2009.02242.x.

DENG, J. et al. Effects of replacing fish meal with soy protein concentrate on feed intake and growth of juvenile Japanese flounder, Paralichthys olivaceus. Aquaculture, v.258, p.503513, 2006. Available from: <http://www.sciencedirect.com/ science/article/pii/S004484860600250X>. Accessed: dec. 12, 2008. doi: http://dx.doi.org/10.1016/j.aquaculture.2006.04.004.

ESCAFFRE, A.M. et al. Nutritional value of soy protein concentrate for larvae of common carp (Cyprinus carpio) based on growth performance and digestive enzyme activities. Aquaculture, v.153, p.63-80, 1997. Available from: <http:// www.sciencedirect.com/science/article/pii/S0044848697000100>. Accessed: dec. 12, 2008. doi: http://dx.doi.org/10.1016/S00448486(97)00010-0.

ESCAFFRE, A.M. et al. Morphometric evaluation of changes in the digestive tract of rainbow trout (Oncorhynchus mykiss) due to fish meal replacement with soy protein concentrate. Aquaculture, v.273, p.127-138, 2007. Available from: <http:/ / w w w.sciencedirect.com/s cience/article/pi i / S0044848607009210>. Accessed: nov. 11, 2009. doi: http:// dx.doi.org/10.1016/j.aquaculture.2007.09.028.

FILIPETTO, J.E. et al. Substituição de fígado bovino por glúten de milho, glúten de trigo e farelo de soja em rações para pós-larvas de piavas (Leporinus obtusidens). Ciência Rural, v.35, p.192-197, 2005. Available from: <http://www.scielo.br/ pdf/cr/v35n1/a31v35n1.pdf $>$ Accessed: apr. 22, 2005. doi: http://dx.doi.org/10.1590/S0103-84782005000100031.

GOVONI, J.J. et al. The physiology of digestion in fish larvae. Environmental Biology of Fishes, v.16, p.59-77, 1986 Available from: <http://rd.springer.com/article/10.1007/ BF00005160>. Accessed: jun. 25, 2010. doi: 10.1007/ BF00005160.

HARDY, R.W. Utilization of plant proteins in fish diets: effects of global demand and supplies of fishmeal. Aquaculture Research, v.41, p.770-776, 2010. Available from: <http:// onlinelibrary.wiley.com/doi/10.1111/j.13652109.2009.02349.x/pdf $>$. Accessed: may 11, 2010. doi: 10.1111/j.1365-2109.2009.02349.x.

HERNÁNDEZ, D.R. et al. Fontes não convencionais de proteína na primeira alimentação do bagre sul americano (Rhamdia quelen). Ciência Rural, v.39, p.878-884, 2009. Available from: <http:// www.scielo.br/scielo.php? script $=$ sci_arttext\&pid $=$ S010384782009000300037\&lng=pt\&nrm=iso $>$. Accessed: may 26 , 2009. doi: http://dx.doi.org/10.1590/S0103-84782009005000019.

HOPKINS, K.D. Reporting fish growth: a review of the basics. Journal of the World Aquaculture Society, v.23, p.173179, 1992. Available from: <http://onlinelibrary.wiley.com/doi/ 10.1111/j.1749-7345.1992.tb00766.x/pdf >. Accessed: apr. 3, 2012. doi: $10.1111 / \mathrm{j} .1749-7345.1992 . t b 00766 . x$.

OLSEN, R.E. et al. Total replacement of fish meal with plant proteins in diets for Atlantic cod (Gadus morhua L.) II- Health aspects. Aquaculture, v.272, p.612-624, 2007. Available from: $<$ http://www.sciencedirect.com/science/article/pii/ S0044848607004206>. Accessed: sep. 2, 2010. http:// dx.doi.org/10.1016/j.aquaculture.2007.05.010.

OSTASZEWSKA, T. et al. Growth and morphological changes in the digestive tract of rainbow trout (Oncorhynchus mykiss) and pacu (Piaractus mesopotamicus) due to casein replacement with soybean proteins. Aquaculture, v.245, p.273-286, 2005 Available from: <http://www.sciencedirect.com/science/article/ 
pii/S0044848604007215>. Accessed: dec. 12, 2008. doi: http:/ /dx.doi.org/10.1016/j.aquaculture.2004.12.005.

PIAIA, R.; RADÜNZ NETO, J. Avaliação de diferentes fontes protéicas sobre o desempenho inicial de larvas do jundiá Rhamdia quelen. Ciência Rural, v.27, p.319-323, 1997 Available from: <http://www.scielo.br/pdf/cr/v27n2/ a25v27n2.pdf>. Accessed: nov. 9, 2009. doi: http://dx.doi.org/ 10.1590/S0103-84781997000200025.

REFSTIE, S. et al. Feed consumption and conversion in Atlantic salmon (Salmo salar) fed diets with fish meal, extracted soybean meal or soybean meal with reduced content of oligosaccharides, trypsin inhibitors, lectins and soya antigens. Aquaculture, v.162, p.301-312, 1998. Available from: <http:// ww w.sciencedirect.com/s cience/article/pi i/ S0044848698002221>. Accessed: oct. 19, 2010. doi: http:// dx.doi.org/10.1016/S0044-8486(98)00222-1.

REFSTIE, S. et al. Differing nutritional responses to dietary soybean meal in rainbow trout (Oncorhynchus mykiss) and Atlantic salmon (Salmo salar). Aquaculture, v.190, p.4963, 2000. Available from: <http://www.sciencedirect.com/science/ article/pii/S0044848600003823>. Accessed: oct. 11, 2009. doi: http://dx.doi.org/10.1016/S0044-8486(00)00382-3.

REFSTIE, S. et al. Digestive capacity, intestinal morphology, and microflora of 1-year and 2-year old Atlantic cod (Gadus morhua) fed standard or bioprocessed soybean meal. Aquaculture, v.261, p.269-284, 2006. Available from: <http:/ / www.sciencedirect.com/science/article/pii/ S0044848606005059>. Accessed: dec. 12, 2008. doi: http:// dx.doi.org/10.1016/j.aquaculture.2006.07.011.
SANTIGOSA, E. et al. Effect of diets containing a purified soybean trypsin inhibitor on growth performance, digestive proteases and intestinal histology in juvenile sea bream (Sparus aurata L.). Aquaculture Research, v.41, p.187-198, 2010. Available from: <http://onlinelibrary.wiley.com/doi/10.1111/ j.1365-2109.2010.02500.x/pdf>. Accessed: aug. 25, 2008. doi: 10.1111/j.1365-2109.2010.02500.x.

SISSENER, N.H. et al. An assessment of organ and intestinal histomorphology and cellular stress response in Atlantic salmon (Salmo salar L.) fed genetically modified Roundup Ready ${ }^{\circledR}$ soy. Aquaculture, v.298, p.101-110, 2009. Available from: <http:/ / w w w.sciencedirect.com/science/article/pii/ S0044848609008382>. Accessed: nov. 11, 2009. doi: http:// dx.doi.org/10.1016/j.aquaculture.2009.10.011.

ULIANA, O. et al. Substituição parcial ou total de óleo de canola por lecitina de soja em rações para larvas de jundiá (Rhamdia quelen), pisces, Pimelodidae. Ciência Rural, v.31, p.677-681, 2001. Available from: <http://www.scielo.br/pdf/cr/ v31n4/a19v31n4.pdf>. Accessed: apr. 22, 2005. doi: http:// dx.doi.org/10.1590/S0103-84782001000400019.

URÁN, P.A. et al. Soybean meal-induced enteritis in Atlantic salmon (Salmo salar L.) at different temperatures. Aquaculture Nutrition, v.14, p.324-330, 2008. Available from: <http://onlinelibrary.wiley.com/doi/10.1111/j.13652095.2007.00534.x/pdf $>$. Accessed: nov. 11, 2009. doi: 10.1111/j.1365-2095.2007.00534.x.

YÚFERA, M. et al. A highly efficient microencapsulated food for rearing early larvae of marine fish. Aquaculture, v.177, p.249-256, 1999. Available from: <http://www.sciencedirect.com/ science/article/pii/S0044848699000885>. Accessed: nov. 24, 2009. doi: http://dx.doi.org/10.1016/S0044-8486(99)00088-5. 